Diabetologia (1994) 37: 36-42

\title{
Altered endothelin-1 induced contraction and second messenger generation in bovine retinal microvascular pericytes cultured in high glucose medium
}

\author{
U.Chakravarthy ${ }^{1}$, A. McGinty ${ }^{2}$, J. McKillop ${ }^{3}$, P. Anderson ${ }^{2}$, D. B. Archer ${ }^{1}$, E. R. Trimble ${ }^{2}$ \\ ${ }^{1}$ Department of Ophthalmology, Queen's University of Belfast, Belfast, UK \\ ${ }^{2}$ Department of Clinical Biochemistry, Queen's University of Belfast, Belfast, UK \\ ${ }^{3}$ Department of Medicine, Queen's University of Belfast, Belfast, UK
}

Summary The effect of simulated hyperglycaemia on bovine retinal pericytes was studied following culture of these cells for 10 days under normal $(5 \mathrm{mmol} / \mathrm{l})$ and elevated $(25 \mathrm{mmol} / \mathrm{l})$ glucose conditions in the absence of endothelial cells. Pericytes cultured under high ambient glucose exhibited both a delayed and reduced contractile response following stimulation with endothelin-1. Stimulation with $10^{-7} \mathrm{~mol} / 1$ endothelin-1 for $30 \mathrm{~s}$ caused significant contraction in cells grown in both $5 \mathrm{mmol} / 1$ and $25 \mathrm{mmol} / 1$ glucose. The former also contracted significantly with $10^{-8} \mathrm{~mol} / 1$ endothelin-1. Further, at all concentrations tested, statistical comparison of the time course of contraction showed a significant difference $(p<0.02)$ in the reduction of planimetric surface area between the two cell groups. Since neither binding of endothelin-1 nor the number of receptors for this peptide were significantly different $(p>0.1)$ between bovine retinal pericytes grown for 10 days under normo- or hyperglycaemic conditions, it became apparent that the altered contractility in bovine retinal pericytes following culture in high glucose must be due to post-binding intracellular disturbance(s). Indeed, both basal and $15 \mathrm{~s}$ post-stimulation with $10^{-8} \mathrm{~mol} / 1$ endothelin- 1 , levels of inositol trisphosphate were significantly reduced $(p<0.05$ and $p<0.02$, respectively) in pericytes cultured for 10 days in $25 \mathrm{mmol} / \mathrm{lglucose}$. These results show that endothelialindependent alterations in contractility of pericytes occur when they are grown in conditions which simulate hyperglycaemia. The results also suggest that the observed attenuation in response to endothelin-1 stimulation evident in pericytes grown under simulated hyperglycaemic conditions is not due to alterations in peptide binding. [Diabetologia (1994) 37: 36-42]

Key words Retinal microvascular pericytes, hyperglycaemia, endothelin-1, inositol $(1,4,5)$ trisphosphate.
The retinal microcirculation is devoid of extrinsic innervation and there is evidence that under normal conditions retinal blood flow may be regulated by changes in smooth muscle and pericyte tone mediated by endothelium-derived autacoids acting in paracrine fashion [1]. Recent work has shown that retinal capillary endothelial cells secrete endothelin-1 (ET-1), a potent vasoconstrictor, and that corresponding pericytes bear receptors to this peptide, suggesting the presence of a

Received: 8 March 1993

and in revised form: 20 July 1993

Corresponding author: Prof. E. R. Trimble, Department of Clinical Biochemistry, Institute of Clinical Science, Royal Victoria Hospital, Belfast BT12 6BJ, UK specific interactive system for the control of retinal blood flow [2]. ET-1 was first characterized and sequenced from the supernatant of cultured porcine aortic endothelial cells by Yanagisawa et al. [3]. It is the most potent vasoconstrictor known, causing contraction of vascular strips from humans and experimental animals in vitro [4], and is highly effective at the microcirculatory level [5]. We have previously demonstrated that ET-1 induces rapid increases in intracellular inositol $(1,4,5)$ trisphosphate $\left[\operatorname{Ins}(1,4,5) \mathrm{P}_{3}\right]$ levels in cultured retinal pericytes and causes a sustained contraction response in these cells [6]. ET-1 also acts as a co-mitogen in pericytes in the presence of low levels of fetal calf serum [6]. These findings underline the importance of ET-1 as a paracrine modulator of pericyte function and replication. 
Maintenance of normal vascular tone and the control of blood flow within tissues is a result of finelytuned responses of the effector cells (which are the smooth muscle or its analogue in the microvasculature, the pericyte) to neural and humoral stimuli and endothelium-derived factors. The presence of an intact endothelium in vascular preparations has been shown to be a prerequisite for the induction of the vasodilator response to substances such as acetylcholine [7] which cause a release of endothelium-derived relaxing factor (EDRF) from endothelial cells [8]. In contrast, a variety of vasoactive agents, both dilator and constrictor, can also act on the effector cells independently of the endothelium [7,9]. Vascular tissues derived from animal models of diabetes [10] and blood vessels incubated in vitro in a milieu containing high glucose concentrations [11] show reduced relaxation with acetylcholine. However, no abnormality of relaxation was seen with the calcium ionophore A23187 which is also endothelium-dependent $[11,12]$ nor with sodium nitroprusside which is endothelium-independent in its action [12]. McVeigh et al. [13] have provided evidence for reduced relaxation to both endothelium-dependent and endothelium-independent stimuli in Type 2 (non-insulin-dependent) diabetic subjects. In Type 1 (insulin-dependent) diabetic patients Halkin et al. [14] found no difference in the relaxation caused by an analogue of acetylcholine or sodium nitroprusside in forearm vessels when compared to control subjects. By contrast, in short-term diabetes in an animal model others have provided evidence consistent with increased production of EDRF and increased vascular relaxation [15]. Thus, the relative roles of the endothelial and muscle cells in vascular dysfunction in diabetes are unclear.

In diabetes changes in retinal microcirculatory haemodynamics can occur early in the disease [16] preceding structural abnormalities [17] suggesting that functional abnormalities of either endothelial or contractile effector cells or both may be implicated in the early stages of diabetic microangiopathy. It is also known that the hyperglycaemia of diabetes causes glycation of membrane proteins which may result in the modification of receptor density and structure, thereby interfering with the binding of agonists and so impairing transmembrane signalling [18]. In view of the above the aim of the present study was to investigate the effect of high glucose concentrations on the contractility of cultured retinal microvascular pericytes in the absence of endothelial cells. ET-1 induced contraction, the binding of ${ }^{125} \mathrm{I}-\mathrm{ET}-1$ to cell-surface receptors, and subsequent second messenger generation have been measured in microvascular pericytes propagated in conditions simulating normo- and hyperglycaemia.

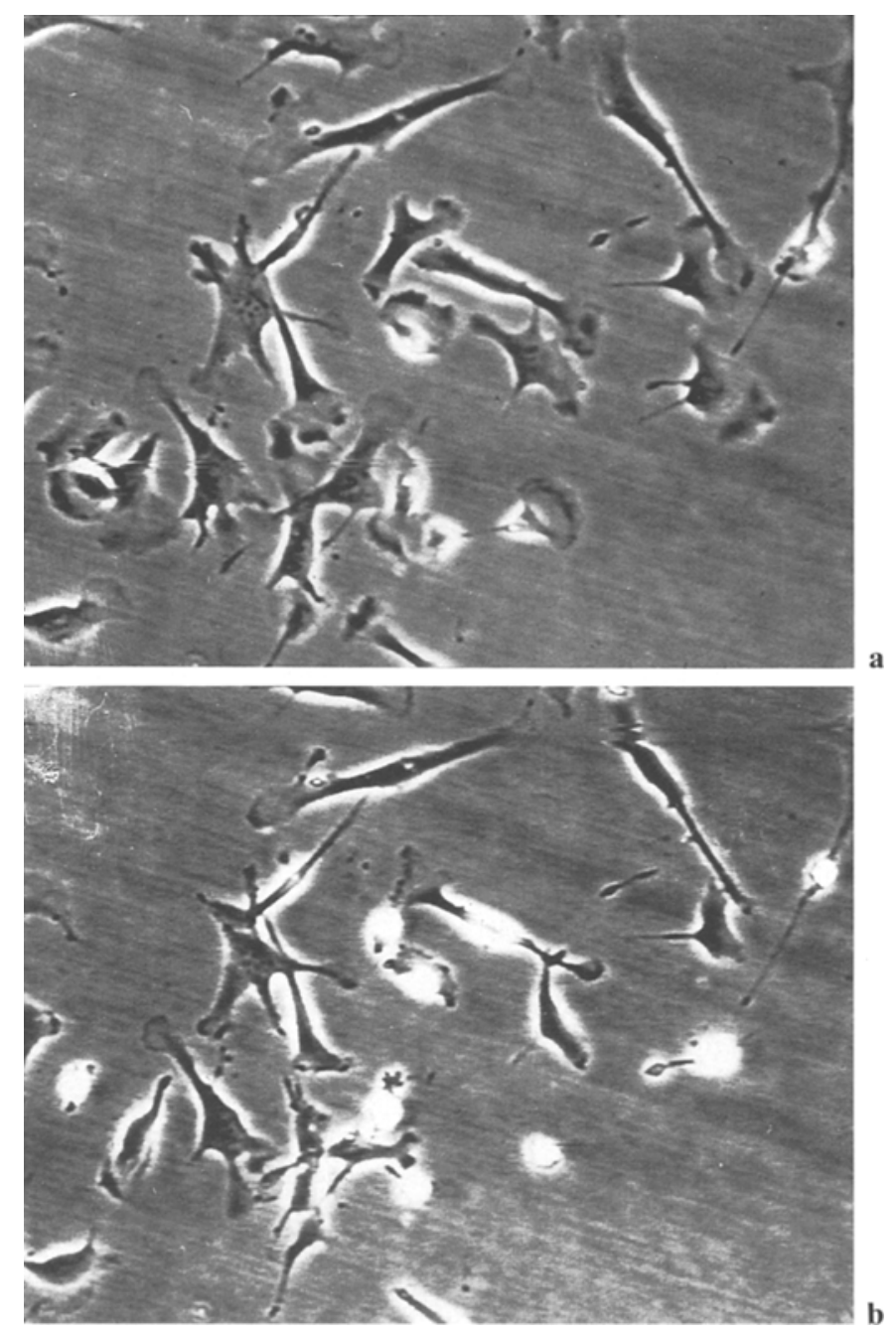

Fig.1. (a,b) Photographs representing cells incubated in $5 \mathrm{mmol} / \mathrm{l}$ glucose before (a) and $5 \mathrm{~min}$ post (b) endothelin-1 $\left(10^{-8} \mathrm{~mol} / \mathrm{l}\right)$ addition

\section{Materials and methods}

\section{Cell culture}

Bovine eyes were obtained from the abattoir, and the retinae isolated and homogenised. The microvascular fragments were subjected to microscopically controlled enzyme digestion and collected on a $53 \mu \mathrm{m}$ mesh as described by Gitlin and D'Amore [19]. The fragments were propagated in $25 \mathrm{~cm}^{2}$ flasks (Falcon, Becton Dickinson UK Ltd, Cowley, UK) in Dulbecco's modified Eagles medium (DMEM, Gibco, Paisley, UK) containing $15 \%$ fetal calf serum (FCS; Gibco, Paisley, UK), and antibiotics as previously described in detail [6]. Bovine retinal pericytes (BRP) formed a confluent layer within 14 days, and were stained for muscle-specific actins using immunocytochemical techniques to confirm their identity. The lack of staining to monoclonal anti-factor VIII and polyclonal anti-endothelin in such cultures was used to confirm the absence of endothelial cells which are the only likely contaminants.

Passage 2 to 5 BRP were used for all experiments. The cells were maintained in medium containing normal glucose $(5 \mathrm{mmol} / \mathrm{l})$ or high glucose $(25 \mathrm{mmol} / \mathrm{l})$ and growth curves demonstrated that cells propagated in the high glucose medium suf- 


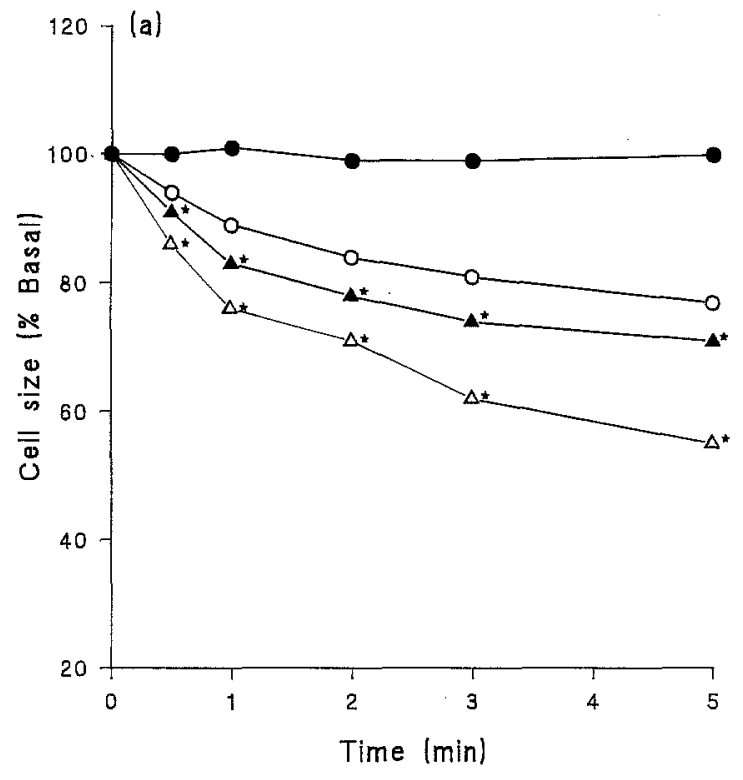

Fig. 2. (a,b) The effect of endothelin-1 (ET-1) on planimetric surface area of pericytes incubated in (a) $5 \mathrm{mmol} / 1$ or (b) $25 \mathrm{mmol} / \mathrm{lglucose}$ for 10 days. This shows the response in a typical experiment to ET-1 at appropriate concentrations compared to controls - control; $O, 10^{-9} \mathrm{~mol} / 1 ; \Delta, 10^{-8} \mathrm{~mol} / \mathrm{l}$ and $\triangle, 10^{-7}$ $\mathrm{mol} / \mathrm{l}$. Results are expressed as \% of basal planimetric area (time 0). Statistical analyses were made using Spearman rank correlation coefficient and the Wilcoxon test for matched pairs. Significant differences relative to control are noted $\left({ }^{*} p<0.05\right)$ and the differences in response at $t=5 \mathrm{~min}$ between $5 \mathrm{mmol} / \mathrm{l}$ and $25 \mathrm{mmol} / 1$ incubated cells are also marked $(\# p<0.05)$. Each point represents a minimum of five observations

fered inhibition of growth on a par with that reported by others $[20,21]$. Adjustment of the osmolality of the medium containing $5 \mathrm{mmol} / \mathrm{l}$ glucose to that of medium containing $25 \mathrm{mmol} / 1 \mathrm{glu}-$ cose with mannitol did not influence cell growth.

\section{Studies on planimetric surface area measurements}

Pericytes were seeded on to $35 \mathrm{~mm}$ petri dishes at $2 \times 10^{4}$ cells per dish in DMEM $10 \%$ FCS and maintained in $5 \mathrm{mmol} / \mathrm{l}$ or $25 \mathrm{mmol} / \mathrm{l}$ glucose for 10 days. Cells were maintained in serumfree medium for $24 \mathrm{~h}$ prior to stimulation. The plates were placed on a Nikon phase microscope fitted with a warming stage which was maintained at $37^{\circ} \mathrm{C}$. The cultures were washed with Hank's balanced salt solution (HBSS). At zero time fresh DMEM containing the desired concentration of ET-1 (Cambridge Research Biochemicals, Cambridge, UK) was added. The cultures were subjected to continuous time-lapse video recording for 5 min from the beginning of stimulation with ET-1. All video tapes were coded and given to the observer in blinded fashion. Using a frame grabber, recordings generated at $0,0.5,1$, 2,3 and 5 min were analysed on a Kontron Vidas image analyser. Planimetric cell surface area was measured by means of a handheld cursor which was used to outline the perimeter of each cell. In some experiments cells were pre-relaxed with forskolin $10^{-5} \mathrm{~mol} / 1$ (Sigma Chemical Co., Poole, UK) (an elevator of intracellular cyclic adenosine monophosphate) for $10 \mathrm{~min}$ before stimulation with ET-1. (b)

\section{Iodination of ET-1}

Radiolabelled ET-1 was prepared using the Iodogen reagent. Briefly, ET-1 was incubated with Iodogen (Pierce \& Warriner, [UK] Ltd., Chester, UK) and $\mathrm{Na}^{125} \mathrm{I}$ (Amersham, Little Chalfont, $\mathrm{UK}$ ) for $20 \mathrm{~min}$ at room temperature in $50 \mathrm{mmol} / \mathrm{l}$ phosphate buffer ( $\mathrm{pH} 7.2$ ). The reaction mixture was then purified by reverse phase HPLC on a Waters C18 uBondapak HPLC system. Suitable fractions were stored in an equal volume of $1 \%$ (volume/volume) acidified ethanol at $-20^{\circ} \mathrm{C}$. The specific activity of stored aliquots was determined by the method of Morris [22].

\section{Binding experiments}

Pericytes were seeded at an initial density of $2 \times 10^{4}$ cells per well in 24-well plates in DMEM containing 5 or $25 \mathrm{mmol} / \mathrm{I}$ glucose for 10 days. Cells were serum starved for $24 \mathrm{~h}$ prior to carrying out binding studies. All incubations were performed in the following medium: $140 \mathrm{mmol} / \mathrm{l} \mathrm{NaCl}, 4 \mathrm{mmol} / \mathrm{K} \mathrm{KCl}, 1 \mathrm{mmol} / / \mathrm{Na}_{2} \mathrm{HPO}_{4}$, $1 \mathrm{mmol} / \mathrm{l} \mathrm{MgCl} 2,1.25 \mathrm{mmol} / \mathrm{l} \mathrm{CaCl} 2,11 \mathrm{mmol} / \mathrm{l}$ glucose, $5 \mathrm{mmol} / \mathrm{l}$ Hepes ( $\mathrm{pH} 7.2$ ), and $0.2 \%$ BSA. The wells were washed with binding buffer and incubated in various concentrations of ${ }^{125} \mathrm{I}$-labelled ET-1 either for $16-24 \mathrm{~h}$ at $4^{\circ} \mathrm{C}$ or $90 \mathrm{~min}$ at $37^{\circ} \mathrm{C}$ in the presence or absence of an excess of cold peptide. Replicates numbered 2-6 in different experiments. Cells were washed twice with ice cold medium and then lysed using $0.1 \mathrm{~mol} / 1 \mathrm{NaOH}$. Radioactivity associated with lysed cells was counted on an NE 1600 gamma counter. Specific binding was calculated as total binding minus non-specific binding in the presence of $10^{-7} \mathrm{~mol} / \mathrm{l}$ unlabelled ET-1. The binding of labelled ET-1 to BRP was analysed by the method of Woolf [23].

\section{Inositol $(1,4,5)$ trisphosphate measurements}

BRP from a common cell pool were seeded at $2.5 \times 10^{6}$ cells $/ 75 \mathrm{~cm}^{2}$ (Falcon) flasks and maintained until confluence in $5 \mathrm{mmol} / \mathrm{l}$ or $25 \mathrm{mmol} / \mathrm{l}$ glucose for 10 days. The cultures were serum starved for $48 \mathrm{~h}$, washed several times with Krebs solution at $37^{\circ} \mathrm{C}$ and stimulated with $10^{-8} \mathrm{~mol} / \mathrm{l} \mathrm{ET}-1$. At 


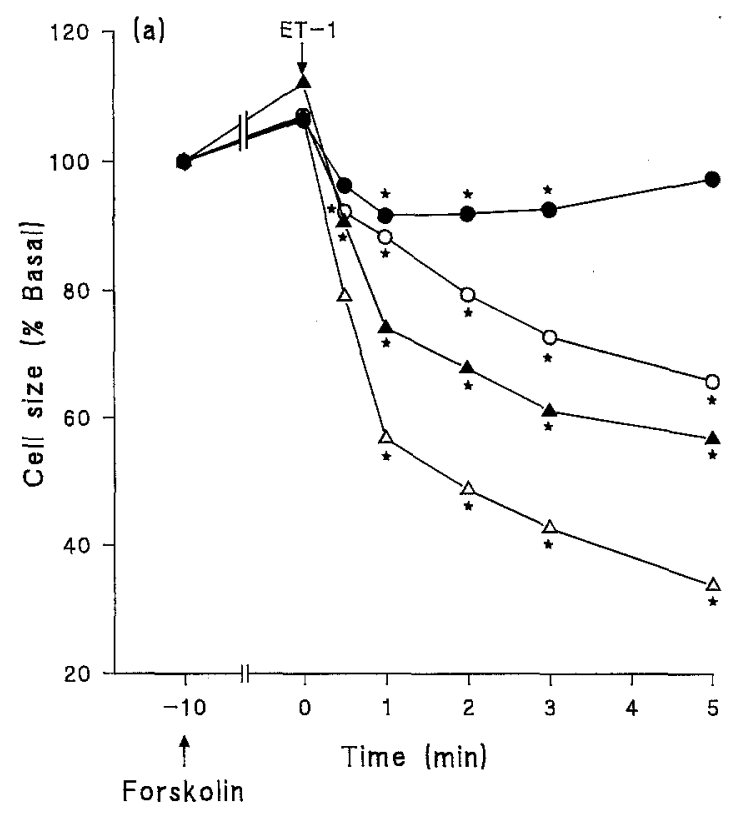

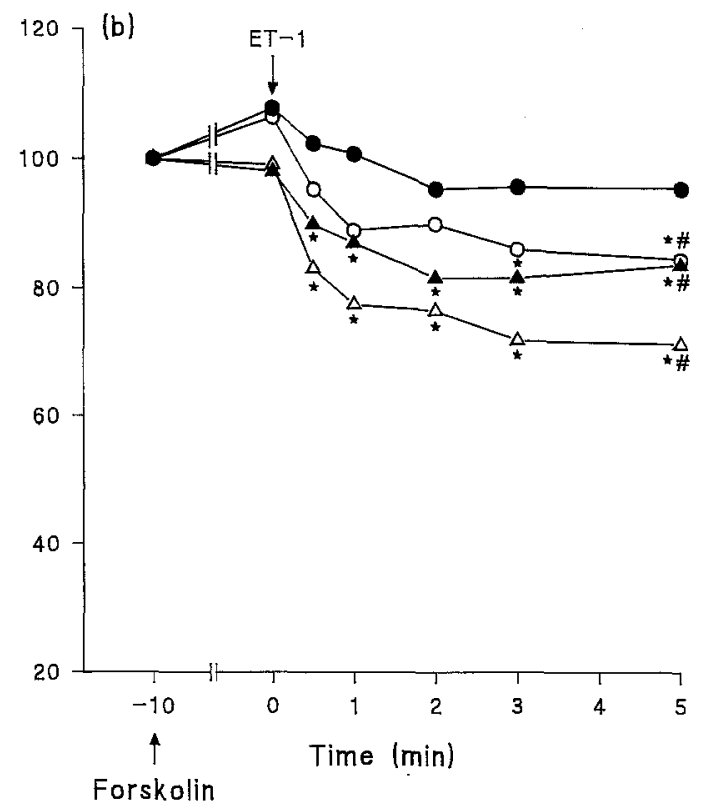

Fig. 3. (a,b) The effect of endothelin-1 (ET-1) on planimetric surface area of pericytes incubated in (a) $5 \mathrm{mmol} / \mathrm{l}$ glucose and (b) $25 \mathrm{mmol} / \mathrm{l}$ glucose after pre-relaxation of cells with forskolin $\left(10^{-5} \mathrm{~mol} / \mathrm{l}\right)$ for a period of $10 \mathrm{~min}$. Changes in planimetric area are calculated and analysed as in Figure 2 with $100 \%$ defined as the cell size prior to relaxation with forskolin. Symbols are as for Figure 2. Statistical comparisons were made between results at $\mathrm{t}=-10 \mathrm{~min}$ and all other times $\left({ }^{*} p<0.05\right)$ and between data at $\mathrm{t}=5 \mathrm{~min}$ for $5 \mathrm{mmol} / \mathrm{l}$ and $25 \mathrm{mmol} / \mathrm{l}$ glucose $(\# p<0.05)$. Each point represents a minimum of 20 observations

appropriate time points, the reaction was stopped by the addition of ice-cold trichloroacetic acid, final concentration $10 \%$. The flasks were maintained on ice for $30 \mathrm{~min}$ and the cells harvested and pelleted by centrifugation at $2000 \times \mathrm{g}$ for $30 \mathrm{~min}$. The supernatants were decanted and stored at $-20^{\circ} \mathrm{C}$ prior to assay for $\operatorname{Ins}(1,4,5) \mathrm{P}_{3}$. The pellet was extracted for DNA measurements according to Tsanev and Markov [24]. Ins $(1,4,5) \mathrm{P}_{3}$ measurements were performed using a commercial radioreceptor assay kit (Dupont UK Ltd., Stevenage, UK).

\section{Statistical analysis}

Statistical analysis was performed using Spearman's Rank correlation coefficient, Wilcoxon test for matched pairs and the paired $t$-test as appropriate.

\section{Results}

\section{Planimetric surface area}

We have previously shown a dose and time-dependent reduction in planimetric surface area in pericytes following stimulation with ET-1 [6]. Sequential phase micrographs showing the change in planimetric surface area following exposure to agonists are shown in Fig- ure 1. The response to ET-1 in pericytes cultured under conditions simulating hyperglycaemia for 10 days was reduced when compared with cells cultured in $5 \mathrm{mmol} / \mathrm{l}$ glucose (Fig. 2). Thus, at the earliest time point of $30 \mathrm{~s}$ with $25 \mathrm{mmol} / \mathrm{l}$ glucose, there was a significant reduction in surface area of cells only with $10^{-7} \mathrm{~mol} / \mathrm{l} \mathrm{ET}-1$, while with $5 \mathrm{mmol} / \mathrm{l}$ glucose both $10^{-8} \mathrm{~mol} / 1$ and $10^{-7} \mathrm{~mol} / 1 \mathrm{ET}-1$ caused significant contraction at the 30 s time point $(p<0.02)$. Furthermore, if the complete time courses of contraction are analysed, at concentrations of $10^{-8} \mathrm{~mol} / 1$ and $10^{-7} \mathrm{~mol} / \mathrm{l} \mathrm{ET}-1$ there were significantly reduced responses in high glucose- as opposed to normal glucose-cultured cells $(p<0.01$ for both concentrations, Spearman's rank correlation coefficient). In addition, if the response at the single time point of $5 \mathrm{~min}$ is analysed, the results show that at all concentrations of ET-1 tested the reductions in planimetric surface area were less for cells grown in $25 \mathrm{mmol} / \mathrm{l}$ compared with $5 \mathrm{mmol} / \mathrm{l}$ glucose $(p<0.05$ for all three concentrations, Wilcoxons test for matched pairs). In a second series of experiments pericytes were pre-relaxed with forskolin in case cells grown in $25 \mathrm{mmol} / \mathrm{l}$ glucose were more contracted under basal conditions than those grown under $5 \mathrm{mmol} / \mathrm{l}$ glucose. Pre-relaxation of cells with forskolin enhanced the intensity of response to ET-1 in cells grown in both normal and high glucose (Fig.3). For example, $5 \mathrm{~min}$ after stimulation with $10^{-7} \mathrm{~mol} / \mathrm{l}$ ET-1 cell surface area was reduced by $65 \%$ vs $28 \%$ (normal vs high glucose) post-forskolin and $37 \%$ vs $23 \%$ (normal vs high glucose) without pre-relaxation. However, under pre-relaxed conditions, ET-1 still elicited a greater change in surface area of cells grown in $5 \mathrm{mmol} / \mathrm{l}$ than those in $25 \mathrm{mmol} / \mathrm{l}$ glucose $(p<0.02$ for each concentration of ET-1, Spearman's correlation coefficient). 


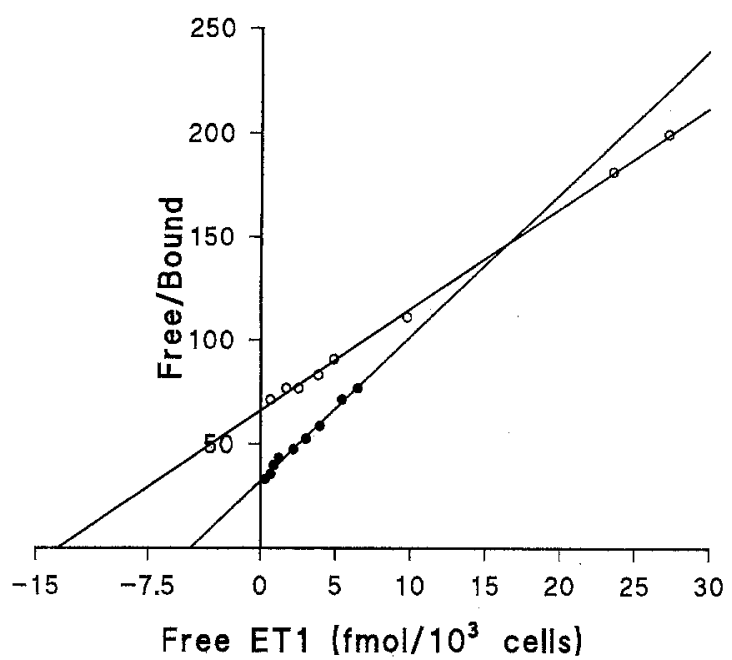

Fig.4. Woolf plot showing specific binding of ${ }^{125}$ I-endothelin-1 (ET-1) at $4^{\circ} \mathrm{C}$ to bovine retinal pericytes propagated in $5(\bullet)$ or $25 \mathrm{mmol} / \mathrm{l}(\mathrm{O})$ glucose for 10 days. The dissociation constant $\mathrm{K}_{\mathrm{d}}$ for pericytes cultured in $5 \mathrm{mmol} / \mathrm{l}$ glucose was $25.9 \pm 12.6 \times 10^{-11}$ $\mathrm{mol} / \mathrm{l}$ and the number of binding sites per cell was $1.42 \pm 0.29 \times 10^{5}$. Cells cultured in $25 \mathrm{mmol} / \mathrm{l}$ glucose had a $K_{d}$ of $19.7 \pm 15.4 \times 10^{-11} \mathrm{~mol} / 1$ and $1.07 \pm 0.13 \times 10^{5}$ binding sites per cell. There was no significant difference in $\mathrm{K}_{\mathrm{c}}$ or number of binding sites per cell when $5 \mathrm{mmol} / \mathrm{l}$ and $25 \mathrm{mmol} / \mathrm{l}$ glucose were compared $(p>0.05)$. Results are given as mean \pm SD of $K_{d}$ and binding site numbers for three independent experiments

Table 1. Effect of $10^{-8} \mathrm{~mol} / \mathrm{l}$ endothelin- 1 on generation of Ins $(1,4,5) \mathrm{P}_{3}$ in bovine retinal microvascular pericytes cultured in the presence of $5 \mathrm{mmol} / \mathrm{l}$ or $25 \mathrm{mmol} / 1$ glucose for 10 days

\begin{tabular}{clll}
\hline & \multicolumn{3}{l}{ Ins $(1,4,5) \mathrm{P}_{3} \mathrm{pg} / \mathrm{DNA} \mu \mathrm{g}$} \\
\cline { 2 - 4 } & Basal & $15 \mathrm{~s}$ & $30 \mathrm{~s}$ \\
\hline $5 \mathrm{mmol} / \mathrm{l}$ glucose & $0.30 \pm 0.18$ & $0.69 \pm 0.29^{\mathrm{a}}$ & $0.65 \pm 0.15^{\mathrm{a}}$ \\
$25 \mathrm{mmol} / \mathrm{lglucose}$ & $0.21 \pm 0.11^{\mathrm{b}}$ & $0.48 \pm 0.14^{\mathrm{a}, \mathrm{c}}$ & $0.52 \pm 0.16^{\mathrm{a}}$ \\
\hline
\end{tabular}

${ }^{\mathrm{a}} p<0.05$ compared to basal; ${ }^{\mathrm{b}} p<0.05,{ }^{\mathrm{c}} p<0.02$ compared to $5 \mathrm{mmol} / \mathrm{lglucose}$

Ins $(1,4,5) \mathbf{P}_{3}$ was measured in triplicate flasks in each experiment. Results are shown as mean \pm SEM from eight independent experiments. In each experiment pericytes from the same cell pool were incubated in either $5 \mathrm{mmol} / 1$ or $25 \mathrm{mmol} / 1$ glucose. Statistical comparisons were made using the Wilcoxon test for paired samples

\section{Binding of ${ }^{125} I-E T-1$ to cultured BRP}

Neither at $4^{\circ} \mathrm{C}$ nor $37^{\circ} \mathrm{C}$ did the concentration of glucose ( 5 vs $25 \mathrm{mmol} / \mathrm{l}$ ) cause a significant alteration in the apparent dissociation constant $\left(\mathrm{K}_{\mathrm{d}}\right)$ or receptor number for ET-1. The results for $4^{\circ} \mathrm{C}$ are shown in Figure $4\left(37^{\circ} \mathrm{C}\right.$ results not shown $)$.

\section{Inositol (1,4,5) trisphosphate measurements}

ET-1 $\left(10^{-8} \mathrm{~mol} / \mathrm{l}\right)$ caused a significant generation of Ins $(1,4,5) \mathrm{P}_{3}$ in pericytes grown in both 5 and $25 \mathrm{mmol} / 1$ glucose as determined by comparing basal levels for
U. Chakravarthy et al.: Altered endothelin-1 induced contraction

each cell group with their levels $15 \mathrm{~s}$ and $30 \mathrm{~s}$ poststimulation (Table 1). However, basal levels of $\operatorname{Ins}(1,4,5) \mathrm{P}_{3}$ were significantly reduced in cells cultured in $25 \mathrm{mmol} / \mathrm{l}$ glucose when compared with $5 \mathrm{mmol} / \mathrm{l}$ glucose $(p<0.05)$. Fifteen seconds following stimulation with $10^{-8} \mathrm{~mol} / 1 \mathrm{ET}-1, \operatorname{Ins}(1,4,5) \mathrm{P}_{3}$ levels were lower in cells cultured in $25 \mathrm{mmol} / 1$ glucose when compared with cells grown in $5 \mathrm{mmol} / \mathrm{l}$ glucose $(p<0.02)$; at $30 \mathrm{~s} \operatorname{Ins}(1,4,5) \mathrm{P}_{3}$ levels were lower in the former but the difference was not significant (Table 1).

\section{Discussion}

The results of this study demonstrate clearly that contractility of BRP can be affected by high ambient glucose concentrations independently of any effect of glucose on endothelial cell function. Exposure of retinal pericytes to $25 \mathrm{mmol} / \mathrm{l}$ glucose for 10 days caused an attenuation of contraction to ET-1 and significantly higher concentrations of the peptide were required to elicit a demonstrable response when compared with cells maintained in $5 \mathrm{mmol} / \mathrm{l}$ glucose. Forskolin, which stimulates adenylate cyclase can dilate constricted arteries under certain conditions [25] and was used in part of the present study to relax pericytes prior to stimulation with ET-1. This was in an attempt to rule out a precontracted state in cells maintained in high glucose concentrations as a reason for their reduced response to ET-1. An enhanced intensity of response to ET-1 following exposure to forskolin was seen in cells propagated in both normal and high concentrations of glucose. However, the differential in the response was unaltered, ruling out a pre-contracted state or increased cell tension as the major reason for the reduced contraction seen in cells exposed during culture to high glucose concentrations. To our knowledge the present work represents the first direct demonstration of reduced contractility to the potent endothelium-derived vasoconstrictor ET-1 in microvascular pericytes.

It has been suggested that the regulation of vascular tone by the endothelium is altered in diabetes. However, such evidence is controversial as some investigators have shown reduced [13], unaltered [14] or enhanced [15] endothelium-dependent relaxation. Our study, although examining the effect of a vasoconstrictor derived from the endothelium in vivo, was carried out in an in vitro model independent of the endothelium. The results provided by the present experiments show that whatever the effect on the endothelium, hyperglycaemia may have a direct effect on the function of the effector cells of the retinal microvessels.

The next question was whether the altered contractility to ET-1 at high glucose concentrations was due to changes at the receptor binding or postbinding level or both. A fairly prolonged exposure to high concentrations of glucose may result in glycation and crosslinking of cell surface proteins and cause non-specific reduc- 
tion in receptor expression for a number of peptides [26]. However, in the present experiments where pericytes were exposed to $25 \mathrm{mmol} / \mathrm{l}$ glucose for relatively short periods of time, there was no reduction in either the $K_{d}$ or the number of binding sites for ET-1 compared to cells grown in $5 \mathrm{mmol} / \mathrm{l}$ glucose: it was also the case for pericytes grown for up to 21 days in high glucose (unpublished observations). This suggested that the altered responsiveness of pericytes grown in $25 \mathrm{mmol} / \mathrm{l}$ glucose to ET-1 was due to changes in postbinding phenomena.

Following binding to its receptor ET-1 stimulates the production of $\operatorname{Ins}(1,4,5) \mathrm{P}_{3}$ and diacylglycerol (DAG) through phospholipase $\mathrm{C}$ induced hydrolysis of $\mathrm{PIP}_{2}$. Previous work has shown that sodium-dependent, ouabain-sensitive myoinositol uptake in BRP is inhibited by elevated glucose concentrations [27]. This results in a decrease in their myoinositol content and is associated with a reduction of both their basal $\mathrm{PIP}_{2}$ levels and phospholipase $\mathrm{C}$ activity [28]. In view of the presumed reduction of both the substrate $\left(\mathrm{PIP}_{2}\right)$ pool and phospholipase $\mathrm{C}$ activity it was not surprising that basal Ins $(1,4,5) \mathrm{P}_{3}$ and $\operatorname{Ins}(1,4,5) \mathrm{P}_{3}$ levels at the earliest time point after ET-1 stimulation (15 s) were lower in cells cultured in $25 \mathrm{mmol} / 1$ glucose than in those cultured in $5 \mathrm{mmol} / 1$ glucose. At $30 \mathrm{~s}$ post-stimulation Ins $(1,4,5) \mathrm{P}_{3}$ levels in cells cultured in $25 \mathrm{mmol} / /$ glucose were also lower than those in $5 \mathrm{mmol} / \mathrm{l}$ glucose but the difference was not significant. A mass $\operatorname{Ins}(1,4,5) \mathrm{P}_{3}$ radioreceptor assay was used instead of tracer labelling with ${ }^{3} \mathrm{H}$ myoinositol to avoid the problems associated with different sized substrate pools. In another report which appeared while this paper was in preparation, ET-1 $10^{-7} \mathrm{~mol} / \mathrm{l}$ had no significant effect on $\operatorname{Ins}(1,4,5) \mathrm{P}_{3}$ levels in pericytes which had been cultured for 6-8 days in medium containing $25 \mathrm{mmol} / \mathrm{l}$ glucose while causing a marked increase in cells grown in $5.5 \mathrm{mmol} / 1$ glucose [29]. These authors did not quote absolute values for Ins $(1,4,5) \mathrm{P}_{3}$ nor state whether basal values for cells grown at $5.5 \mathrm{mmol} / \mathrm{l}$ and $25 \mathrm{mmol} / \mathrm{l}$ glucose differed from each other. However, their results and ours would both be consistent with the proposition that reduced contractility in response to ET-1 of pericytes grown in $25 \mathrm{mmol} / 1$ glucose is related to events which occur following binding of ET-1 to its receptor and not to altered binding itself.

In this study we have analysed only the very early biochemical steps following $\mathrm{PIP}_{2}$ hydrolysis which produce equal amounts of $\operatorname{Ins}(1,4,5) \mathrm{P}_{3}$ and DAG. High glucose concentrations have been shown to cause activation of protein kinase $C(\mathrm{PKC})$ in mesangial cells [30] (which resemble pericytes morphologically) and in vascular smooth muscle cells [31]. Activation of PKC under these circumstances is at least in part due to de novo synthesis of DAG $[32,33]$ from glucose which is independent of agonist-induced $\mathrm{PIP}_{2}$ hydrolysis. The only report of DAG and PKC measurements in pericytes under these conditions are a little difficult to in- terpret in that under basal conditions total DAG measurements did not differ between cells grown at $5.5 \mathrm{mmol} / 1$ and $25 \mathrm{mmol} / 1$ glucose but the PKC activities of the latter group of cells were approximately double the level of those grown at $5.5 \mathrm{mmol} / \mathrm{l}$ glucose [29]. Further work is clearly indicated to unravel the later sequence of events in these cells following ET-1 stimulation.

The present work has shown that exposure of microvascular pericytes grown in culture under conditions of high glucose concentrations have a reduced contractile response to ET-1. Since the pericytes are grown in the absence of endothelial cells the effect is not secondary to endothelial cell dysfunction. Future studies will be aimed at clarifying endothelial cell-mediated pericyte responses in co-cultures maintained under conditions of simulated hyperglycaemia.

Acknowledgements. This work was supported by funds from the British Diabetic Association, the Wellcome Trust, the Juvenile Diabetes Foundation and Lilly Industries Ltd, UK.

\section{References}

1. Dodge AB, Hechtman HB, Shepro D (1991) Microvascular endothelial-derived autacoids regulate pericyte contractility. Cell Motil Cytoskeleton 18: 180-188

2. Takahashi K, Brooks RA, Kanse SM, Ghatei MA, Kohner EM, Bloom SR (1989) Production of endothelin 1 by cultured bovine retinal endothelial cells and presence of endothelin receptors on associated pericytes. Diabetes 38: 1200-1202

3. Yanagisawa M, Kurihara H, Kimura S et al. (1988) A novel potent vasoconstrictor peptide produced by vascular endothelial cells. Nature (Lond) 332:411-415

4. Cocks TM, Broughton A, Dib M, Sudhir K, Angus JA (1989) Endothelin is blood vessel selective: studies on a variety of human and dog vessels in vitro and on regional blood flow in the conscious rabbit. Clin Exp Pharmacol Physiol 16:243-246

5. Brain SD, Crossman DC, Buckley TL, Williams TJ (1989) Endothelin-1: demonstration of potent effects on the microcirculation of humans and other species. J Cardiovasc Pharmacol 13: S147-S149

6. Chakravarthy U, Gardiner TA, Anderson P, Archer DB, Trimble ER (1992) The effect of endothelin 1 on the retinal microvascular pericyte. Microvasc Res 43: 241-254

7. Furchgott RF (1983) Role of endothelium in responses of vascular smooth muscle. Circ Res 53: 557-573

8. Palmer RMJ, Ferridge AG, Moncada S (1987) Nitric oxide release accounts for the biological activity of endotheliumderived relaxing factor. Nature (Lond) 327: 524-526

9. Pascual R, Bevan JA (1980) Asymmetry of consequences of drug disposition mechanisms in the wall of the rabbit aorta. Circ Res 46: 22-28

10. Meraji S, Jayakody L, Senaratne P, Manohara PJ, Thompson APR, Kappagoda T (1987) Endothelium-dependent relaxation in aorta of BB rat. Diabetes 36: 978-984

11. Tesfamariam B, Brown ML, Deykin D, Cohen RA (1990) Elevated glucose promotes generation of endotheliumderived vasoconstrictor prostanoids in rabbit aorta. J Clin Invest 85 : 929-932

12. Tesfamariam B, Jakubowski JA, Cohen RA (1989) Contraction of diabetic rabbit aorta due to endothelium-derived $\mathrm{PGH}_{2}-\mathrm{Tx} \mathrm{A}_{2}$. Am J Physiol 257: H1327-H1333 
13. McVeigh GE, Brennan GM, Johnston GD et al. (1992) Impaired endothelium-dependent and independent vasodilation in patients with type 2 (non-insulin-dependent) diabetes mellitus. Diabetologia 35: 771-776

14. Halkin A, Benjamin N, Doktor HS, Todd SD, Viberti G, Ritter JM (1991) Vascular responsiveness and cation exchange in insulin-dependent diabetes. Clin Sci 81: 223-232

15. Corbett JA, Tilton RG, Chang K et al. (1992) Aminoguanidine, a novel inhibitor of nitric oxide formation, prevents diabetic vascular dysfunction. Diabetes 41: 552-556

16. Grunwald JE, Riva CE, Brucker AJ, Sinclair SH, Petrig BL (1991) Altered retinal vascular response to $100 \%$ oxygen breathing in diabetes mellitus. Ophthalmology 91: 1447-1452

17. Cogan DG, Toussaint D, Kuwabara T (1961) Retinal vascular patterns. IV. Diabetic retinopathy. Arch Ophthalmol 66: 366-378

18. Hames HP, Brownlee M (1992) Nonenzymatic glycosylation of macromolecules. Prospects for pharmacologic modulation. In: Ruderman NB, Williamson JR, Brownlee M (eds) Hyperglycemia, diabetes and vascular disease. Oxford University Press, Oxford, pp 218-227

19. Gitlin J, D'Amore PA (1983) Culture of retinal capillary cells using selective growth media. Microvasc Res 26: 74-80

20. Li W, Shen S, Khatami M, Rockey JH (1984) Stimulation of retinal pericytes protein and collagen synthesis in culture by high glucose concentration. Diabetes 33: 785-789

21. King GL, Johnson S, Wu G (1990) Possible growth modulators involved in the pathogenesis of diabetic proliferative retinopathy. In: Westermark B, Betsholtz C, Hokfelt B (eds) Growth factors in health and disease. Excerpta Medica, Amsterdam, pp 303-317

22. Morris BJ (1976) Specific radioactivity of radioimmunoassay tracer determined by self-displacement: a re-evaluation. Clin Chim Acta 73: 213-216

23. Haldane JBS (1957) Graphical methods in enzyme chemistry. Nature (Lond) 179: 832

24. Tsanev R, Markov GG (1960) Substances interfering with spectrophotometric estimation of nucleic acids and their elimination by the two wave-length method. Biochim Biophys Acta 42: 442-452

25. Busija DW, Chen J (1992) Reversal by increased CSF [H+] and $[\mathrm{K}+]$ of phorbol ester-induced arteriolar constriction in piglets. Am J Physiol 263: H1455-H1459

26. Tarsio JF, Reger LA, Furcht LT (1987) Decreased interaction of fibronectin, type IV collagen and heparin due to nonenzymic glycation: implications for diabetes mellitus. Biochemistry 26: 1014-1020

27. Li W, Chan LS, Khatami M, Rockey JH (1986) Non-competitive inhibition of myoinositol transport in cultured bovine retinal capillary pericytes by glucose and reversal by Sorbinil. Biochim Biophys Acta 857: 198-208

28. Li W, Tang L, Zhou Q, Qin M, Hu T (1989) Attenuation of phosphoinositidase activity and phosphatidylinositol bisphosphate level of bovine retinal capillary pericytes in high glucose. Exp Eye Res 48: 99-106

29. De La Rubia G, Oliver FJ, Inoguchi T, King GL (1992) Induction of resistance to endothelin-1's biochemical actions by elevated glucose levels in retinal pericytes. Diabetes 41 : 1533-1539

30. Studer RK, Craven PA, DeRubertis FR (1993) Role for protein kinase $C$ in the mediation of increased fibronectin accumulation by mesangial cells grown in high-glucose medium. Diabetes 42: 118-126

31. Williams B, Schrier RW (1992) Characterization of glucoseinduced in situ protein kinase $\mathrm{C}$ activity in cultured vascular smooth muscle cells. Diabetes 41: 1464-1472

32. Ayo SH, Radnik R, Garoni JA, Troyer DA, Kreisberg JI (1991) High glucose increases diacylglycerol mass and activates protein kinase $C$ in mesangial cell cultures. Am J Physiol 261: F571-F577

33. Wolf BA, Williamson JR, Easom RA, Chang K, Sherman WR, Turk J (1991) Diacylglycerol accumulation and microvascular abnormalities induced by elevated glucose levels. J Clin Invest 87: 31-38 